\title{
PENERAPAN ANALISIS FUNDAMENTAL TERHADAP PERUSAHAAN PERTAMBANGAN TBK DALAM MEMBELI SAHAM
}

\author{
Yetti Afrida Indra \\ IAIN Bengkulu, Indonesia \\ Email : yetti.afrida@iainbengkulu.ac.id
}

\begin{abstract}
The purpose of this research is to find out the influence Fundamental analysis ( of price earning ratio, earning per share, dividend per share, and dividend payout ratio) to the enhancement of mining companies' stock price in 2014 - 2018 periods. The sample collection technique has been done by using purposive sampling method, and the samples are 6 companies. The statistic test method has been done by using multiple linier regression analysis. The independent variables in this research are price earning ratio, earning per share, dividend per share, and dividend payout ratio. The dependent variable is stock price. The result of this research show that price earning ratio, earning per share, dividend per share have significant and positive influence to the stock price. Meanwhile, dividend payout ratio have significant and negative influence to the stock price. It can be seen from the result of partial coefficient determination and it can be concluded that the variable which has dominant influence to the stock price is dividend per share because its partial coefficient determination is bigger than other independent variables.
\end{abstract}

Keywords : PER, EPS, DPS, DPR, stock price.

Abstrak: Penelitian ini bertujuan untuk mengetahui pengaruh Analisis fundamental (price earning ratio, earning per share, dividend per share, dan dividend payout ratio) terhadap kenaikan harga saham perusahaan pertambangan selama periode 2014 - 2018. Adapun teknik pengambilan sampel menggunakan metode purposive sampling, dengan jumlah sampel yang digunakan dalam penelitian ini sebanyak 6 perusahaan. Metode pengujian statistik yang digunakan dalam penelitian ini adalah analisis regresi linier berganda. Variabel yang digunakan dalam penelitian ini yaitu price earning ratio, earning per share, dividend per share, dan dividend payout ratio sebagai variabel independen. Harga saham sebagai variabel dependen. Hasil penelitian menunjukkan bahwa price earning ratio, earning per share, dan dividend per share berpengaruh positif dan signifikan terhadap harga saham. Sedangkan dividend payout ratio berpengaruh negatif dan signifikan terhadap harga saham. Melihat dari hasil koefisien determinasi parsial dari penelitian ini disimpulkan bahwa variabel yang berpengaruh dominan terhadap harga saham adalah dividend per share karena mempunyai koefisien determinasi partialnya paling besar diantara variabel independen lainnya.

Kata Kunci : PER, EPS, DPS, DPR, harga saham.

\section{A. PENDAHULUAN}

Perkembangan industri pertambangan yang pesat ini mendorong meningkatnya investasi baik lokal maupun asing di sektor tersebut. Sektor pertambangan masih sangat diminati investor, melihat rata-rata kinerja perusahaan di sektor itu yang mengalami pertumbuhan. Pertumbuhan perusahaan yang baik ini mencerminkan kualitas kinerja yang baik dalam sektor pertambangan.

Semakin baiknya prospek di industri pertambangan ini maka menarik para investor untuk dapat berinvestasi dalam industri tersebut. Hal ini juga didukung dengan pasar modal Indonesia yang sedang tumbuh dan memiliki kontribusi yang tinggi dalam perekonomian.

Setiap pengambilan keputusan investasi memerlukan pertimbangan dan 
analisis yang mendalam untuk menjamin keamanan dana yang diinvestasikan serta keuntungan yang diharapkan. Calon investor harus mengetahui keadaan dan prospek perusahaan yang menjual surat berharganya dengan melakukan analisis terhadap saham perusahaan. Dalam melakukan analisis saham terdapat dua pendekatan dasar yang dilakukan yaitu analisis teknikal dan analisis fundamental.

Pentingnya analisis terhadap faktorfaktor fundamental untuk tujuan investasi jangka panjang yang tercermin dari rasiorasio keuangan tersebut, dapat dijadikan bahan pertimbangan bagi para investor dalam menentukan keputusan investasi yang tentunya akan berdampak terhadap nilai perusahaan.

Nilai perusahaan di sini sangat penting karena dapat mencerminkan kinerja perusahaan yang dapat mempengaruhi persepsi investor terhadap perusahaan. Jadi semakin tinggi nilai perusahaan semakin besar kemakmuran yang akan diterima pemilik perusahaan ${ }^{1}$.

Oleh sebab itu, kondisi seperti ini menjadi tantangan sendiri bagi manajemen perusahaan agar keputusan keuangan yang diambil bisa meningkatkan kinerja perusahaan dan pada akhirnya dapat meningkatkan nilai perusahaan.

\footnotetext{
${ }^{1}$ Harmono, Manajemen Keuangan. (Jakarta: Bumi Aksara, 2009), hlm. 17
}

Meningkatnya nilai perusahaan tersebut dapat menarik minat para investor untuk menanamkan modalnya.

Beberapa data yang digunakan untuk menganalisis Fundamental yaitu Berita perusahaan yang bisa didapatkan dari media elektronik maupun media cetak, Data ekonomi bisa didapatkan melalui Bank Indonesia ataupun Badan Pusat Statistik, dan Data laporan keuangan perusahaan yang dirilis setiap 3 bulan sekali (kuartalan).

Beberapa kegunaan Analisis Fundamental yaitu Membantu memilih saham yang bagus untuk investasi, Mengetahui bagaimana kondisi perekonomian suatu negara, dan Mengetahui harga wajar suatu saham. Rasio dalam Analisis Fundamental yaitu EPS (Earning Per Share) atau laba per saham, PER (Price Earning Ratio) atau rasio harga saham dibanding laba perusahaan, PBV (Price to Book Value Ratio) atau rasio harga saham dibanding nilai akunting perusahaan, ROE (Return On Equity) atau rasio laba dibanding modal perusahaan, DER (Debt Equity Ratio) atau rasio utang perusahaan dibanding modalnya ${ }^{2}$.

Dari pendahuluan diatas,

$\begin{array}{lllll}{ }^{2} \text { Husnan, Dasar-Dasar } & \text { Teori } & \text { Portofolio dan } \\ \text { Analisis } \quad \text { Sekuritas, } & \text { (Yogyakarta: } & \text { UPP } & \text { AMP } \\ \text { YKPN,2005), hlm. 351 } & & & \end{array}$


Perubahan harga saham dalam merespon perubahan kondisi perekonomian yang terjadi berbeda-beda antara satu perusahaan dengan perusahaan lain meskipun perusahaan tersebut bergerak dalam bidang industri yang sama. Besarnya penurunan yang dialami oleh hampir seluruh perusahaan pertambangan pada tahun 2014, 2015, 2016, 2017 dan 2018 menjadi permasalahan tersendiri bagi pengusaha maupun calon investor, untuk itu diperlukan perluasan penelitian yang didukung oleh teori yang mendasar, maka diajukan permasalahan analisis fundamental yang mampu memprediksi perubahan harga saham, dimana terdapat empat variabel yang diduga berpengaruh terhadap perubahan harga saham. Keempat variabel tersebut adalah earning per share, price to earning ratio, debt to equity ratio,dan return on equity.Untuk itu peneliti tertarik untuk menganalisis variabel yang mempengaruhi harga saham perusahaan-perusahaan di sektor pertambangan yang terdaftar di Bursa Efek Indonesia periode tahun 2014-2018 yang dengan judul penelitian "Penerapan Analisis Fundamental Terhadap Perusahaan Pertambangan Tbk Dalam Membeli Saham”.

\section{B. LANDASAN TEORI}

\section{Pasar Modal}

Pasar modal adalah instrumen keuangan yang memperjual belikan surat-surat berharga berupa obligasi dan ekuitas atau saham untuk melakukan investasi jangka panjang, yang kegiatannya dilaksanakan di bursa. Pasar modal adalah pertemuan antara pihak yang memiliki kelebihan dana dengan pihak yang membutuhkan dana dengan cara memperjualbelikan sekuritas. Dengan demikian, pasar modal juga bisa diartikan sebagai pasar sekuritas yang umumnya memiliki umur lebih dari satu tahun $^{3}$.

\section{Investasi}

Investasi adalah akumulasi suatu bentuk aktiva dengan harapan memperoleh keuntungan di masa depan. Investasi pada hakikatnya merupakan penempatan sejumlah dana pada saat ini dengan harapan untuk memperoleh keuntungan di masa mendatang. Umumnya investasi dibedakan menjadi dua, yaitu investasi pada asset-aset finansial (financial assets) dan investasi pada asset-aset riil (real assets).

\section{Saham}

Saham merupakan membeli

${ }^{3}$ Halim A, Analisis Investasi, (Jakarta: Salemba Empat, 2003), hlm. 63 
sebagian kepemilikan perusahaan dan berhak atas perolehan keuntungan yang disebut dividen. Saham adalah tanda bukti penyertaan kepemilikan modal atau dana pada suatu perusahaan ${ }^{4}$. Dengan kertas yang tercantum dengan jelas nilai nominal, nama perusahaan dan diikuti dengan hak dan kewajiban yang dijelaskan kepada setiap pemegangnya yang siap untuk dijual. Saham digunakan sebagai salah satu alat untuk mencari tambahan dana $a^{5}$.

Harga saham merupakan harga yang terbentuk dari penawaran dan permintaan pada pasar, sehingga harga saham suatu perusahaan dapat berubah-ubah. Artinya perubahan harga saham terhantung kepada pihak emiten yang menawarkan saham dan para pialang saham sebagai yang mengajukan permintaan. Harga saham yang cenderung naik mempunyai dampak adanya capital gain, atau dapat menggambarkan kondisi perusahaan yang cenderung cukup baik atau mempunyai prospek jangka panjang yang menjanjikan. Dan sebaliknya,

${ }^{4}$ Fahmi, I, Manajemen Investasi: Teori dan Soal Jawab, (Jakarta: Salemba Empat, 2012), hlm. 102-323

${ }^{5}$ Ibid,. harga saham cenderung turun, dapat mengakibatkan capital loss, dan permintaan saham juga akan turun, hal ini menunjukkan kekurangan percayaan para investor terhadap kemampuan prospek jangka panjang perusahaan.

a. Price Earning Ratio (PER)

$$
\text { Price earning ratio }
$$

merupakan rasio yang sering digunakan oleh analis saham untuk menilai harga saham ${ }^{6}$. Pada dasarnya PER memberikan indikasi tentang jangka waktu yang diperlukan untuk mengembalikan dana pada tingkat harga saham dan keuntungan perusahaan pada suatu periode tertentu. Oleh karena itu, rasio ini menggambarkan kesediaan investor membayar suatu jumah tertentu untuk setiap rupiah perolehan laba perusahaan, sehingga PER dapat dihitung dengan rumus sebagai berikut :

$$
\begin{aligned}
& \boldsymbol{E} \\
& \mathrm{R}
\end{aligned}=\frac{\text { Price }}{\text { Earning Per Share }}
$$

Keterangan :

Price : Harga saham yang dibeli

\footnotetext{
${ }^{6}$ Halim, Analisis Investasi. (Jakarta: Salemba Empat, 2005). hlm. 27
} 
Earning Per Share : Laba per saham

Rasio ini diperlihatkan oleh investor dalam memilih saham karena perusahaan yang mempunyak PER yang tinggi menunjukkan nilai pasar yang tinggi pula atas saham tersebut, sehingga saham tersebut akan diminati oleh investor dan hal ini ada akhirnya akan berdampak pada kenaikan harga saham, sebaliknya apabila perusahaan mempunyai PER yang rendah menunjukkan nilai pasar yang rendah sehingga akan berdampak terhadap penurunan harga saham. $^{7}$

\section{b. Earning Per Share (EPS)}

Informasi EPS atau laba per lembar saham menunjukkan besarnya laba bersih perusahaan yang sap dibagikan bagi semua pemegang saham perusahaan. Laba per lembar saham dapat dijadikan sebagai indikator tingkat nilai perusahan. Laba perlembar saham juga merupakan salah satu cara untuk mengukur keberhasilan dalam mencapai keuntungan bagi para pemilik saham dalam perusahaan. Berikut rumus perhitungan EPS:

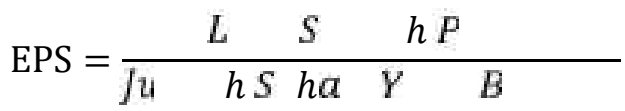

${ }^{7}$ Husnan, Dasar-Dasar Teori Portofolio dan Analisa Sekuritas. Edisi Ketiga. (Yogyakarta: UPP AMP YKPN, 2001)
Earning per share memiliki hubungan yang positif dengan harga saham $^{8}$. Peningkatan laba per lembar saham akan mempengaruhi hasil pengembalian yang berhak diperoleh investor dalam bentuk dividen dan capital gain. Semakin tinggi EPS maka semakin tinggi pula suatu saham, dan sebaliknya semakin rendah EPS maka semakin rendah pula suatu saham tersebut sehingga investor enggan menanamkan modalnya.

\section{c. Dividend Per Share (DPS)}

Dividen adalah pembagian keuntungan yang diberikan perusahaan penerbit saham tersebut atas keuntungan yang dihasilkan perusahaan. Dividen yang tinggi akan meningkatkan harga saham perusahaan Karena memiliki prospek baik. Dividen per lembar saham (DPS) adalah besarnya pembagian dividen yang dibagikan kepada pemegang saham setelah dibandingkan dengan rata-rata tertimbang saham biasa yang beredar. Rumus perhitungan DPS adalah ${ }^{9}$ :

\footnotetext{
${ }^{8}$ Tandelilin. E, Analisis Investasi dan Manajemen Portofolio, (Yogyakarta: BPFE, 2001), hlm. 45

${ }^{9}$ Irawati, S, Manajemen Keuangan. (Bandung: PT. Pustaka, 2006), hlm . 89.
} 


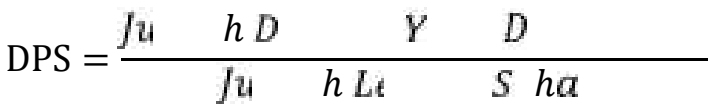

\section{d. Dividend Payout Ratio (DPR)}

$D P R$ merupakan presentase tertentu dari laba perusahaan yang dibayarkan sebagai dividen kas kepada pemegang saham. $D P R$ merupakan keputusan mengenai kebijakan dividen, apakah laba dibagi dalam bentuk dividen atau sebagian diinvestasikan kembali. DPR menunjukkan besarnya laba yang akan dibayarkan kepada pemegang saham dalam bentuk dividen. Semakin besar laba yang diperoleh semakin besar dividen yang dibayarkan, demikian pula sebaliknya bila laba kecil dividen yang dibayarkan juga kecil $^{10}$. Berikut adalah rumus perhitungan $D P R^{11}$ :

$$
\mathrm{DPR}=\frac{T \quad D}{N \quad I \Lambda}
$$

Tetapi ada beberapa perusahaan yang membagikan

\footnotetext{
${ }^{10}$ Sutrisno, Manajemen Keuangan: Teori, Konsep, dan Aplikasi. (Yogyakarta: Ekonisia, 2009.), hlm. 75

${ }^{11}$ Baridwan, Z. Intermediate Accounting. (Yogyakarta: BPFE, 2004), hlm. 91
}

dividen dengan prosentase kecil, hal ini dikarenakan keuntungan yang didapat oleh perusahaan akan dialihkan pada laba ditahan. Digunakan perusahaan untuk mengembangkan bisnisnya dan menerbitkan saham baru. Terdapat teori tax differential theory yaitu teori yang mengemukakan bahwa investor cenderung menyukai dividen yang kecil karena pajak yang akan dibayarkan mengikuti jumlah dividen yang dibayarkan. Dan sebaliknya, apabila dividen besar maka pajak yang dibayarkan juga akan besar. Hal ini sangat memberatkan investor, investor juga lebih suka menerima capital gain. Karena pembayaran pajak akan dibayarkan apabila investor menjual sahamnya dan memperoleh keuntungan.

\section{Hipotesis}

H1: Variabel Price earning ratio berpengaruh terhadap harga saham pada perusahaan pertambangan di Bursa Efek Indonesia.

$\mathrm{H} 2$ : Variabel earning per share berpengaruh terhadap harga saham pada perusahaan 
pertambangan di Bursa Efek

Indonesia.

H3 : Variabel dividend per share berpengaruh terhadap harga saham pada perusahaan pertambangan di Bursa Efek Indonesia.

H4 : Variabel dividend payout ratio berpengaruh terhadap harga saham pada perusahaan pertambangan di Bursa Efek Indonesia.

H5 : Variabel dividend per share berpengaruh dominan terhadap harga saham pada perusahaan pertambangan di Bursa Efek Indonesia.

\section{Gambar 1. Kerangka Konseptual}

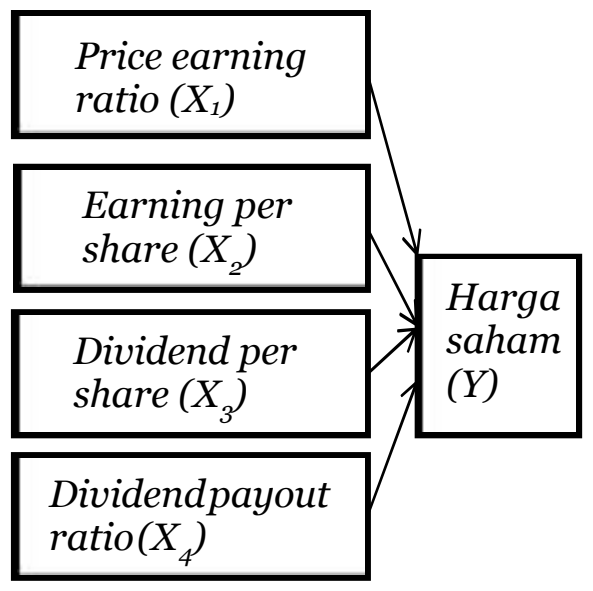

\section{C.METODE PENELITIAN}

Desain penelitian ini adalah penelitian kausal komparatif. Penelitian kausal komparatif (causal-comparative research) adalah penelitian yang menunjukkan arah hubungan antara variabel bebas (x) dengan variabel terikat $(\mathrm{y}),{ }^{12}$ disamping mengukur kekuatan hubungannya. Penelitian ini merupakan tipe penelitian ex post facto, yaitu tipe penelitian terhadap data yang dikumpulkan setelah terjadinya suatu fakta atau peristiwa. Penelitian ini termasuk penelitian hubungan sebab akibat (causal comparative).

Adapun populasi dalam penelitian ini yaitu semua perusahaan pertambangan yang terdaftar di Bursa Efek Indonesia sebanyak 44 perusahaan. Teknik pengambilan sampel menggunakan purposive sampling, dengan kriteria sebagai berikut:

1. Perusahaan pertambangan yang terdaftar di Bursa Efek Indonesia pada Tahun 2014-2018.

2. Perusahaan yang mempublikasikan kinerja perusahaan per 31 Desember yang lengkap secara berturut-turut pada tahun 2014-2018.

3. Perusahaan yang membagikan dividen yang lengkap secara berturut-turut pada tahun 20142018.

Berdasarkan kriteria tersebut di atas, maka diperoleh 6 perusahaan yang dapat dijadikan sampel, diantaranya:

\footnotetext{
${ }^{12}$ Sangadji, E. M. dan Sopiah. Metodologi Penelitian-Pendekatan Praktis dalam Penelitian. (Jakarta : CV. Andi Offset, 2010), hlm. 102
} 
1. PT. Adaro Energy Tbk.

2. PT. Indo Tambangraya Megah Tbk

3. PT. Tambang Batubara Bukit Asam

Tbk

\section{PT. Radiant Utama Interinsco Tbk}

5. PT. Timah Tbk

6. PT. Vale Indonesia Tbk

Sumber data yang digunakan dalam penelitian ini adalah data sekunder yang berasal dari Bursa Efek Indonesia tahun 2014 sampai dengan tahun 2018.

Adapun variabel yang digunakan dalam penelitian ini adalah sebagai berikut :

\section{Price Earning Ratio (PER) :} Informasi price earning ratio menunjukkan besarnya harga setiap satu rupiah earning perusahaan.

2. Earning Per Share (EPS) : Informasi earning per share suatu perusahaan menunjukkan besarnya laba bersih perusahaan yang siap dibagikan bagi semua pemegang saham perusahaan.

\section{Dividen Per Share (DPS) : Dividen} per lembar saham (DPS) adalah besarnya pembagian dividen yang akan dibagikan kepada pemegang saham setelah dibandngkan dengan rata-rata tertimbang saham biasa yang beredar.

4. Dividen Payout Ratio (DPR) : Rasio yang menunjukkan prosentase dari laba per lembar saham yang akan dibayarkan kepada pemegang saham sebagai dividen dalam bentuk cash dividen.

5. Harga Saham : Harga saham biasa yang diterbitkan oleh perusahaan, dimana harga tersebut adalah harga pasar.Harga pasar yang digunakan dalam pengujian statistik adalah harga pasar pada akhir tahun pada saat closing price. Teknik pengukuran variabel menggunakan satuan rupiah.

Teknik analisis data menggunakan aplikasi SPSS v.23. Berikut adalah tahapan analisis data yang dilakukan:

1. Analisis Regresi Linier Berganda

Analisis regresi linier berganda adalah suatu prosedur statistik dalam menganalisis hubungan antara variabel satu atau lebih variabel independen (X) terhadap variabel dependen (Y) rumus multiple regrresinya adalah sebagai berikut ${ }^{13}$ :

$\mathrm{HS}=\alpha+\beta 1 \mathrm{PER}+\beta 2 \mathrm{EPS}+\beta 3 \mathrm{DPS}+\beta 4 \mathrm{DPR} . \mathrm{e}$

Keterangan:

$\mathrm{HS}=$ Harga saham

$\mathrm{A}=$ Konstanta

b1, b2, b3, b4

$\mathrm{PER}=$ Price earning ratio

$\mathrm{EPS}=$ Earning per share

$\mathrm{DPS}=$ Dividend per share

$\mathrm{DPR}=$ Dividend payout ratio

${ }^{13}$ Ferdinan, A. Metode Penelitian Manajemen: Pedoman Penelitian Unuk Skripsi, Tesis, dan Disertai Ilmu Manajemen. (Semarang: Penerbit Universitas Diponegoro 2006), hl m. 201 
$\mathrm{e}=$ Faktor pengganggu dari luar model(error)

2. Uji Asumsi Klasik

Untuk menentukan persamaan regresi dengan metode kuadrat terkecil (ordinary least square) layak digunakan dalam analisis, maka data yang diolah memenuhi 4 asumsi klasik, yaitu uji normalitas, uji mutikoleniaritas, uji autokorelasi, dan uji heterokedastisitas. Uji tersebut dimaksudkan agar persamaan regresi yang dihasilkan tidak biasa dan teruji ketetapannya. Berikut adalah pengujian asumsi klasik:

\section{Uji Normalitas}

Uji normalitas data dalam penelitian ini dapat dilakukan dalam pendekatan grafik uji normalitas menguji apakah dalam sebuah model regresi, baik variabel dependen maupun variabel independen atau keduanya mempunyai distribusi normal atau tidak. Model regresi yang baik adalah distribusi data normal atau mendekati normal.$^{14}$ Cara untuk mendeteksi apakah residual berdistribusi normal atau tidak yaitu dengan analisis garifk dengan metode normal probability plot. Distribusi normal akan membentuk satu

14 Santoso, S, Menggunakan SPSS untuk Statistik Non Parametrik. (Jakarta: PT. Elex Media Komputindo, 2006), hlm. 65 garis lurus diagonal, dan ploting data residual akan dibandingkan dengan garis diagonal. Jika distribusi data residual normal, maka garis yang menggambarkan data sesungguhnya akan mengikuti garis diagonalnya. Jika data menyebar di sekitas garis diagonal dan mengikuti arah garis diagonal, maka model regresi memenuhi asumsi normalitas. Sedangkan, jika data menyebar jauh dari garis diagonal dan/atau tidak mengikuti arah garis diagonal, maka model regresi tidak memenuhi normalitas ${ }^{15}$.

\section{Uji Multikolonieritas}

Uji multikolonieritas bertujuan untuk menguji apakah model regresi ditemukan adanya korelasi antar variabel bebas. Model regresi yang baik seharusnya tidak terjadi korelasi di antara variabel bebas. Jika nilai Variance Inflation Factor (VIF) tidak lebih dari 10 dan nilai tolerance (TOL) tidak kurang dari 0,1, maka model dapat dikatakan terbebas dari multikoliniaritas $\mathrm{VIF}=1 /$ tolerance, $\mathrm{jika}$ $\mathrm{VIF}=10$, maka tolerance $=1 / 10=0,1$.

\section{Uji Autokorelasi}

Uji autokorelasi digunakan untuk menguji apakah dalam model

15 Ghozali, I, Aplikasi Analisis Multivariete dengan Program IBM SPSS 19. (Semarang: UNDIP, 2011), hlm. 121 
regresi linear ada korelasi antara kesalahan pengganggu pada periode t dengan kesalahan penggangu pada periode t-1 (sebelumnya). Sebuah model regresi yang baik adalah tidak terdapat autokorelasi. Secara umum untuk menentukan autokorelasi bisa diambil acuan sebagai berikut ${ }^{16}$ :

a. Angka Durbin Watson (D-W) dibawah -2 berarti ada autokorelasi positif.

b. Angka Durbin Watson (D-W) di antara -2 sampai +2 berarti tidak ada autokorelasi.

c. Angka Durbin Watson (D-W) di atas +2 berarti ada autokorelasi negatif.

6. Uji Heterokedastisitas

Uji Heterokedastisitas bertujuan untuk menguji apakah dalam sebuah model regresi terjadi ketidaksamaan varians dari residual dari satu pengamatan ke pengamatan yang lain. Jika varians dari residual dari satu pengamatan ke pengamatan lain tetap, maka disebut homoskedastisitas, dan jika varians berbeda maka disebut heteroskedastisitas. Model regresi yang baik adalah tidak terjadi

16 Santoso, Panduan Lengkap Menguasai Statistik Dengan SPSS, (Jakarta: PT. Elex Media Komputindo, 2009), hlm. 290 heteroskedastisitas $^{17}$. Dasar dalam pengambilan keputusan yaitu :

a. Jika ada pola tertentu, seperti titiktitik yang ada membentuk suatu pola tertentu yang teratur (bergelombang, melebar kemudian menyempit) maka telah terjadi heteroskedastisitas.

b. Jika tidak ada pola yang jelas serta titik-titik menyebar di atas dan dibawah angka 0 pada sumbu $\mathrm{Y}$ maka tidak terjadi heteroskedastisitas.

7. Uji Kelayakan Model

Uji kelayakan model digunakan untuk menguji kelayakan model yang digunakan dalam penelitian. Model goodness of fit dapat diukur dari nilai koefisien determinasi (R2) dan nilai statistik F.

a. Koefisien Determinasi Berganda $\left(\mathrm{R}^{2}\right)$

Uji ini digunakan untuk mengukur tingkat besarnya pengaruh antara variabel bebas (X) seacara bersama-sama (simultan) dengan variabel terikat (Y). Dimana persamaan diatas dihitung dengan menggunakan alat bantu komputer dengan program SPSS 23. Apabila $\mathrm{R}^{2}$

17 Ghozali, I,. Aplikasi Analisis Multivariete dengan Program IBM SPSS 19. (Semarang: UNDIP, 2011), hlm. 134 
berada antara 0 dan $1\left(0 \leq \mathrm{R}^{2} \leq\right.$ 1), berarti :

1) Bila $R^{2}=1$ atau mendekati 1 (semakin besar nilai $\mathrm{R}^{2}$ ), artinya bahwa kontribusi pengaruh variabel bebas (X) terhadap variabel terikat (Y) adalah $100 \%$ dimana model pendekatan yang digunakan adalah tepat.

2) Bila $R^{2}$ mendekati 0 (semakin kecil nilai $\mathrm{R}^{2}$ ), artinya bahwa kontribusi pengaruh variabel bebas (X) terhadap variabel terikat (Y) hampir dikatakan tidak ada.

b. Uji F

Uji F ini digunakan untuk menguji apakah dalam persamaan regresi yang digunakan pada pengaruh price earning ratio, earning per share, dividend per share, dan dividend payout ratio terhadap harga saham perusahaan pertambangan di Bursa Efek Indonesia memiliki model regresi yang layak atau tidak untuk dilakukan pada penelitian ini. Adapun kriteria pengujian secara simultan dengan tingkat signifikan $\alpha=5 \%$ yaitu sebagai berikut:
1) Jika nilai signifikan uji $F>$ 0,05 maka, model persamaan regresi tidak layak pada penelitian.

2) Jika nilai signifikan uji $\mathrm{F}<$ 0,05 maka model persamaan regresi layak pada penelitian.

8. Pengujian Hipotesis

Pengujian hipotesis merupakan proses pembuatan keputusan yang menggunakan estimasi statistik sampel terhadap parameter populasinya, karena pengujian hipotesis sebagai salah satu tujuan utama peneliti ${ }^{18}$.

a. Uji T

Uji $\mathrm{T}$ ini digunakan untuk menguji pengaruh price earning ratio, earning per share, dividen per share, dan dividen payout ratio secara individual terhadap harga saham perusahaan pertambangan di Bursa Efek Indonesia. Kriteria pengujian dengan $\alpha=5 \%$ yaitu:

1) Jika nilai signifikan uji t >0,05 maka secara parsial tidak berpengaruh.

2) Jika nilai signifikan uji $\mathrm{t}<0,05$ maka secara parsial berpengaruh. 
b. Koefisien Determinasi Parsial ( $\left.\mathrm{r}^{2}\right)$

Analisis ini digunakan untuk mengetahui faktor manakah yang dominan berpengaruh antara price earning ratio (X1), earning per share (X2), dividend per share (X3), dan dividend payout ratio (X4) terhadap harga saham perusahaan pertambangan di Bursa Efek Indonesia (Y). Kriteria dalam uji ini adalah jika $r^{2}$ variabel bebas secara parsial menunjukkan angka terbesar, maka variabel tersebut mempunyai pengaruh dominan terhadap variabel terikat.

\section{HASIL DAN PEMBAHASAN \\ 1. Hasil Analisis Regresi Linier Berganda}

Dalam analisis regresi linier berganda, selain mengukur kekuatan hubungan antara dua variabel atau lebih, juga menunjukkan arah hubungan antara variabel dependen dengan variabel independen ${ }^{19}$.

\section{Tabel 1 Hasil Uji Regresi Linier Berganda}

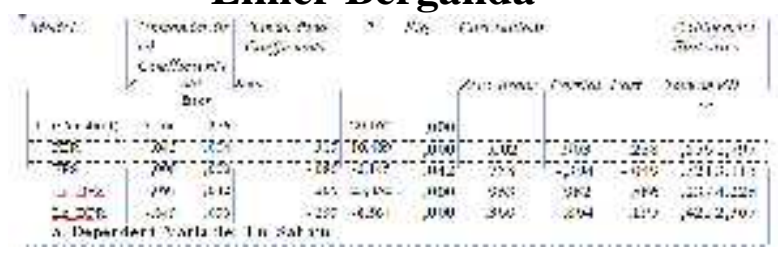

Sumber: data sekunder diolah, 2018

19 Ghozali, I, Aplikasi Analisis Multivariete dengan Program IBM SPSS 19. (Semarang: UNDIP, 2011), hlm. 34
Berdasarkan pada Tabel 1, persamaan regresi yang didapat adalah:

$\mathrm{HS}=5,566+0,043 \mathrm{PER}+0,000 \mathrm{EPS}+$ 1,097Ln_DPS - 0,849Ln_DPR

a. Koefisien regresi PER (b1) sebesar 0,043, menunjukkan arah hubungan positif (searah) antara PER dengan harga saham. Hasil ini mengindikasikan bahwa jika variabel PER naik maka harga saham juga akan naik sebesar 0,043 dengan asumsi variabel lainnya yang konstan.

b. Koefisien regresi EPS (b2) sebesar 0,000, menunjukkan arah hubungan positif (searah) antara EPS dengan harga saham.

c. Koefisien regresi Ln_DPS (b3) sebesar 1,097 menunjukkan arah hubungan positif (searah) antara Ln_DPS dengan harga saham. Hasil ini mengindikasikan bahwa jika variabel Ln_DPS naik maka harga saham juga akan naik sebesar 1,097 dengan asumsi variabel lainnya yang konstan.

d. Koefisien regresi Ln_DPR (b4) sebesar -0,849 menunjukkan arah hubungan negatif (berlawanan arah) antara Ln_DPR dengan harga saham. Hasil ini 
mengindikasikan bahwa jika

variabel Ln_DPR naik maka

harga saham akan turun sebesar -

0,849 dengan asumsi variabel

lainnya yang konstan.

e. Hasil Uji Asumsi Klasik

\section{Uji Normalitas}

Uji normalitas menguji apakah dalam sebuah model regresi, baik variabel dependen maupun variabel independen atau keduanya mempunyai distribusi normal atau tidak. Uji normalitas dengan metode normal p-plot dijelaskan dalam Gambar 2 :

\section{Gambar 2}

\section{Grafik Normal Probability Plot}

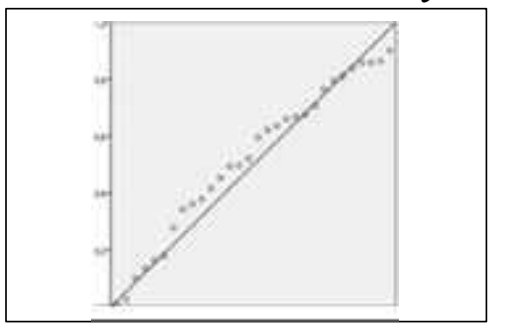

Sumber : data sekunder diolah, 2018

Gambar 2 menunjukkan data menyebar di sekitar garis diagonal. Jadi dapat disimpulkan bahwa data dalam penelitian ini terdistribusi normal.

\section{Uji Multikolonieritas}

Uji multikolonieritas bertujuan untuk menguji apakah model regresi ditemukan adanya korelasi antar variabel bebas. Model regresi yang baik seharusnya tidak terjadi korelasi di antara variabel bebas.
Berikut adalah hasil dari uji multikolonieritas :

Tabel 2 Hasil Uji Multikolonieritas dengan Tolerance dan VIF

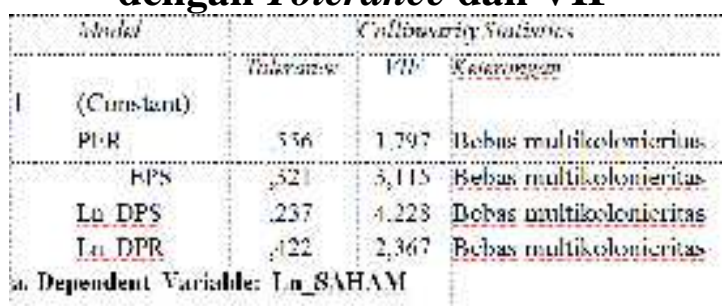

Sumber : data sekunder diolah, 2018

Pada Tabel 2 hasil uji multikolonieritas dengan tolerance dan Varience Inflation Factor (VIF) diketahui nilai tolerance menunjukkan bahwa tidak ada independen yang memiliki nilai tolerance kurang dari 0,10. Hasil perhitungan nilai Varience Inflation Factor (VIF) juga menunjukkan bahwa tidak ada variabel independen yang memiliki nilai VIF lebih dari 10. Jadi dapat disimpulkan bahwa tidak ada multikolonieritas antar variabel independen dalam model regresi.

\section{Uji Heterokedastisitas}

Uji heterokedastisitas bertujuan untuk menguji apakah dalam sebuah model regresi terjadi ketidaksamaan varians dari residual dari satu pengamatan ke pengamatan yang lain. Jika varians dari residual dari satu pengamatan ke pengamatan lain tetap, maka disebut 
homoskedastisitas, dan jika varians berbeda maka disebut heteroskedastisitas. Model regresi yang baik adalah tidak terjadi heteroskedastisitas. Berikut adalah hasil uji heterokedastisitas :

Gambar 3 Heteroskedastisitas pada regresi linier berganda

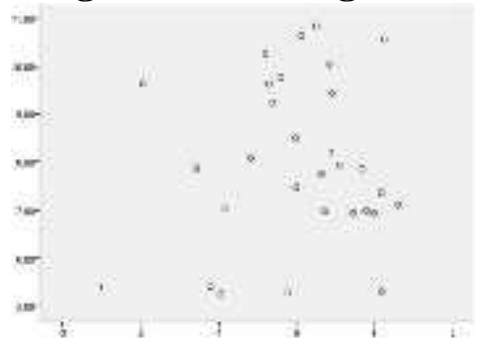

Sumber : Data sekunder diolah, 2018

Dari hasil pengolahan data pada gambar terlihat bahwa pola penyebaran berada diatas dan dibawah pada sumbu Y dan tidak membentuk pola tertentu, maka dapat disimpulkan bahwa model ini tidak terjadi gangguan heteroskedastisitas.

\section{Hasil Uji Kelayakan Model}

a. Koefisien Determnasi Berganda $\left(\mathrm{R}^{2}\right)$

Uji ini digunakan untuk mengukur seberapa jauh kemampuan model dalam menerangkan variasi variabel dependen. Nilai $\mathrm{R}^{2}$ yang kecil berarti kemampuan variabelvariabel independen dalam menjelaskan variasi variabel dependen amat terbatas ${ }^{20}$. Berikut adalah hasil uji koefisien determinasi berganda $\left(\mathrm{R}^{2}\right)$ :

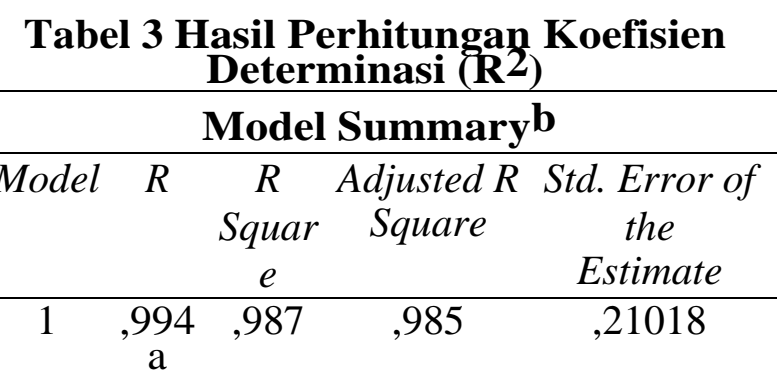

a. Predictors: (Constant), Ln_DPR, EPS, PER, Ln_DPS

b. Dependent Variable: Ln_SAHAM

Sumber: data sekunder diolah, 2018

Berdasarkan Tabel 4 diperoleh nilai R-Square sebesar 0,985. Hal ini menunjukkan bahwa hanya 98,5\% variasi dari harga saham dapat dijelaskan oleh variasi ketiga variabel (PER, EPS, Ln_DPS, Ln_DPR), sedangkan sisanya $1,5 \%$ dijelaskan oleh variabel lain yang tidak masuk dalam model penelitian. Disini hasil $\mathrm{R}^{2}$ sebesar 0,985 atau 98,5\% berarti kemampuan variasi variabel independen dalam menjelaskan variasi variabel dependen sangat tinggi.

b. Uji F

Uji F ini digunakan untuk

${ }^{20}$ Ghozali, I. 2011. Aplikasi Analisis Multivariete dengan Program IBM SPSS 19. Edisi kelima. UNDIP. Semarang, hlm. 256 
menguji apakah dalam persamaan regresi yang digunakan pada pengaruh price earning ratio, earning per share, dividend per share, dan dividend payout ratio terhadap harga saham perusahaan pertambangan di Bursa Efek Indonesia memiliki model regresi yang layak atau tidak untuk dilakukan pada penelitian ini. Berikut adalah hasil uji $\mathrm{F}$ :

\section{Tabel 4 Hasil Perhitungan Uji F}

\begin{tabular}{|c|c|c|c|c|c|}
\hline & \multicolumn{5}{|c|}{ ANOVAa } \\
\hline & Model & $\begin{array}{l}\text { Sust ot } \\
\text { soutares }\end{array}$ & in & $\begin{array}{l}\text { Hean } \\
\text { sogisme }\end{array}$ & $F$ \\
\hline 1 & Regresion & 81.615 & 1 & 21.161 & 180.098 \\
\hline & Resiontus' & 1,102 & 25 &., 144 & \\
\hline & lotal & 85.717 & 29 & & \\
\hline
\end{tabular}

c. Dependent Variable: Ln_SAHAM

d. Predictors: (Constant), Ln_DPR, EPS, PER, Ln_DPS

Sumber: data sekunder diolah, 2018

Dari hasil pengolahan data maka dapat diketahui bahwa data tersebut dapat dikatakan layak untuk dilakukan penelitian. Hal ini dibuktikan dari tingkat signifikan 0,000<0,05. Dengan demikian model regresi $P E R$, $E P S, L n \_D P S, L n \_D P R$ terhadap harga saham layak dalam penelitian ini.

\section{Hasil Pengujian Hipotesis}

a. Uji T

Uji $\mathrm{T}$ ini digunakan untuk menguji pengaruh price earning ratio, earning per share, dividen per share, dan dividen payout ratio seacara individual terhadap harga saham perusahaan pertambangan di Bursa Efek Indonesia ${ }^{21}$. Berikut adalah hasil uji $\mathrm{T}$ :

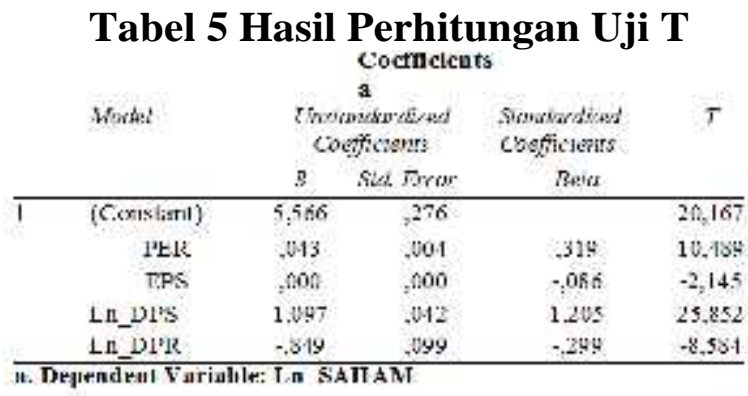

Sumber: data sekunder diolah, 2018

Pada tabel 5 diperoleh hasil perhitungan nilai $\mathrm{t}$ beserta tingkat signifikan dengan penjelasan sebagai berikut:

1) Pengujian Hipotesis PER (X1)

Memiliki nilai t sebesar 10,489 dan hasil probabilitas signifikan sebesar 0,000 berarti $\alpha<0,05$, jadi dapat disimpulkan bahwa variabel PER berpengaruh signifikan terhadap harga saham.

2) Pengujian Hipotesis EPS (X2)

Memiliki nilai t sebesar $-2,145$ dan hasil probabilitas signifikan sebesar $\quad 0,042$ berarti $\alpha<0,05$, jadi dapat disimpulkan bahwa variabel

\footnotetext{
${ }^{21}$ Ghozali, I, Aplikasi Analisis Multivariete dengan Program IBM SPSS 19, (Semarang: UNDIP, 2011), hlm. 243
} 
EPS berpengaruh signifikan

terhadap harga saham.

3) Pengujian Hipotesis Ln_DPS (X3)

Memiliki nilai t sebesar 25,852 dan hasil probabilitas signifikan sebesar 0,000 berarti $\alpha<0,05$, jadi dapat disimpulkan bahwa variabel DPS berpengaruh signifikan terhadap harga saham.

4) Pengujian Hipotesis Ln_DPR (X4)

Memiliki nilai t sebesar -8.584 dan hasil probabilitas signifikan sebesar $\quad 0,000$ berarti $\alpha<0,05$, jadi dapat disimpulkan bahwa variabel Ln_DPR berpengaruh signifikan terhadap harga saham.

b. Koefisien Determinasi Parsial ( $\left.\mathrm{r}^{2}\right)$

Analisis ini digunakan untuk mengetahui faktor manakah yang dominan berpengaruh antara price earning ratio $(\mathrm{X} 1)$, earning per share (X2), dividend per share (X3), dan dividend payout ratio (X4) terhadap harga saham perusahaan pertambangan di Bursa Efek Indonesia (Y). Berikut hasil uji dominan :
Tabel 6 Koefisien Korelasi dan Determinasi Parsial

\begin{tabular}{ccc}
\hline Model & $R$ & $r^{2}$ \\
\hline PER & 0,903 & 0.815409 \\
EPS & $-0,394$ & 0.155236 \\
Ln_DPS & 0.982 & 0.964324 \\
Ln_DPR & $-0,854$ & 0,746496 \\
\hline
\end{tabular}

Sumber: data sekunder diolah, 2018

Dari korelasi parsial pada tabel 6, maka dapat diperoleh koefisien determinasi parsial dengan pengertiannya sebagai berikut:

1) Koefisien determinasi parsial variabel $\mathrm{PER}=0,815409$ yang menunjukkan besarnya kontribusi variabel tersebut terhadap harga saham pada perusahaan pertambangan di Bursa Efek Indonesia sebesar $81,54 \%$.

2) Koefisien determinasi parsial variabel EPS $=0,155236$ yang menunjukkan besarnya kontribusi variabel tersebut terhadap harga saham pada perusahaan pertambangan di Bursa Efek Indonesia sebesar $15,52 \%$.

3) Koefisien determinasi parsial variabel DPS $=0,964324$ yang menunjukkan besarnya kontribusi variabel tersebut terhadap harga saham pada perusahaan pertambangan di Bursa Efek Indonesia sebesar $96,43 \%$. 
4) Koefisien determinasi parsial variabel $\mathrm{DPR}=0,746496$ yang menunjukkan besarnya kontribusi variabel tersebut terhadap harga saham pada perusahaan pertambangan di Bursa Efek Indonesia sebesar $74,64 \%$.

Dari hasil di atas tersebut dapat disimpulkan bahwa variabel yang mempunyai pengaruh dominan terhadap harga saham pada perusahaan pertambangan di Bursa Efek Indonesia adala Dividen Per Share karena mempunyai koefisien determinasi parsial yang besar.

\section{E. KESIMPULAN}

Berdasarkan hasil penelitian secara parsial, maka dapat diambil beberapa simpulan yaitu, hasil penelitian menunjukkan bahwa price earning ratio berpengaruh positif dan signifikan terhadap harga saham perusahaan pertambangan di Bursa Efek Indonesia sebesar 81,54\%. Hal ini menjelaskan bahwa perusahaan memiliki nilai pasar yang tinggi, sehingga dapat menghasilkan keuntungan dan saham akan diminati oleh investor, pada akhirnya akan berdampak pada kenaikan harga saham. Melihat dari hasil koefisien determinasi parsial dari penelitian ini disimpulkan bahwa variabel yang berpengaruh dominan terhadap harga saham adalah divident per share karena mempunya koefisien determinasi partial yang paling besar diantara variabel independen lainnya.

\section{DAFTAR PUSTAKA}

Baridwan, Z. Intermediate Accounting. Edisi Kedelapan. BPFE, 2004, Yogyakarta.

Fahmi, I. 2012. Manajemen Investasi: Teori dan Soal Jawab. Salemba Empat. Jakarta.

- 2014. Manajemen Keuangan Perusahaan dan Pasar Modal. Edisi Pertama. Mitra Wasana Media. Jakarta.

Ghozali, I. 2011. Aplikasi Analisis Multivariete dengan Program IBM SPSS 19. Edisi kelima. UNDIP. Semarang. . 2016. Aplikasi Analisis Multivariete dengan Program IBM SPSS 23. Edisi kedelapan. UNDIP. Semarang.

Ferdinan, A. 2006. Metode Penelitian Manajemen: Pedoman Penelitian Unuk Skripsi, Tesis, dan Disertai Ilmu Manajemen. Badan Penerbit Universitas Diponegoro. Semarang.

Halim, A. 2003. Analisis Investasi. Salemba Empat. Jakarta

. 2005. Analisis Investasi. Edisi Kedua. Salemba Empat. Jakarta.

Husnan, S. 1998. Manajemen Keuangan: Teori dan Penerapan. Edisi Kemepat. BPFE Yogyakarta.

Yogyakarta. 
. 2001. Dasar-Dasar Teori Portofolio

dan Analisa Sekuritas. Edisi Ketiga.

UPP AMP YKPN. Yogyakarta.

. 2005. Dasar-Dasar Teori Portofolio

dan Analisis Sekuritas. Edisi Kemepat.

UPP AMP YKPN. Yogyakarta.

Jogiyanto, H.M. 2010. Metodologi Penelitian

Bisnis: Salah Kaprah dan Pengalaman-

Pengalaman. Edisi Pertama. BPFE.

Yogyakarta.

Irawati, S. 2006. Manajemen Keuangan. Cetakan Pertama. PT. Pustaka. Bandung.

Indriantoro, N. dan Supomo. 2014. Metodologi Penelitian Bisnis Untuk Akuntansi dan Manajemen.

BPFE. Yogyakarta.

Muhammad, S. 2002. Manajemen Stratejik: Konsep dan Kasus. Edisi Ketiga. UPP AMP YKPN. Yogyakarta.

Sangadji, E. M. dan Sopiah. 2010. Metodologi Penelitian-Pendekatan Praktis dalam Penelitian. CV. Andi Offset. Jakarta.

Santoso, S. 2006. Menggunakan SPSS untuk Statistik Non Parametrik. PT. Elex Media Komputindo.Jakarta.

. 2009. Panduan Lengkap Menguasai Statistik Dengan SPSS. PT. Elex Media Komputindo.Jakarta.

Sutrisno, 2009. Manajemen Keuangan: Teori, Konsep, dan Aplikasi. Edisi Pertama. Ekonisia.Yogyakarta.

Tandelilin, E. 2001. Analisis Investasi dan Manajemen Portofolio. BPFE. Yogyakarta. . 2010. Portofolio dan Investasi: Teori dan Aplikasi. Edisi Pertama. Kanisius. Yogyakarta. 